\title{
ポリアクリロニトリル（PAN）ナノファイバー不織布セパレータを用いた リチウムイオン電池の特性
}

\author{
田中政尚 ${ }^{\mathrm{a}, \mathrm{c}, \text { * }}$ ，趙 泰衡 a, 中村達郎 ${ }^{\mathrm{a}}$, 多羅尾 隆 ${ }^{\mathrm{a}}$, 川部雅章 ${ }^{\mathrm{a}}$, 境 哲男 b,c,* \\ a日本バイリーン株式会社（テ 306-0213＼cjkstart茨城県古河市北利根 7 ） \\ b独立行政法人産業技術総合研究所関西センター（† 563-8577 大阪府池田市緑ヶ丘 1-8-31) \\ c神戸大学大学院工学研究科（６57-8501＼cjkstart神戸市灘区六甲台町 1-1）
}

\section{Electrochemical Performances of Polyacrylonitrile Nano-fiber based Nonwoven Separator for Lithium Ion Battery}

\author{
Masanao TANAKA, ${ }^{\mathrm{a}, \mathrm{c}, *}$ Tae-Hyung ChO, ${ }^{\mathrm{a}}$ Tatsuo NAKAmura, ${ }^{\mathrm{a}}$ Takashi Tarao, ${ }^{\mathrm{a}}$ \\ Masaaki KAWABE, ${ }^{\mathrm{a}}$ and Tetsuo SAKAI ${ }^{\mathrm{b}, \mathrm{c}, *}$
}

\author{
a Japan Vilene Co., Ltd. (7 Kita-Tone, Koga, Ibaraki 306-0213, Japan) \\ b National Institute of Advanced Industrial Science and Technology, Kansai (1-8-31 Midorigaoka, Ikeda, Osaka 563- \\ 8577, Japan) \\ c Graduate School of Engineering, Kobe University (1-1 Rokkodai-cho, Nada, Kobe, Hyogo 657-8501, Japan)
}

Received July 27, 2010 ; Accepted September 28, 2010

\begin{abstract}
Two types of polyacrylonitrile (PAN) nano-fiber based nonwovens as separator for lithium ion battery, which consist of different fiber diameters, have been developed by an electrospinning technique. SEM observation exhibited that the electrospun PAN nano-fibers had homogeneous thicknesses, and their diameters were around 250 and $380 \mathrm{~nm}$. The physical, electrochemical and thermal properties of the PAN nonwovens were characterized. The nonwovens possessed homogeneous pore size distribution with similar pore sizes to a polyolefin membrane separator. Moreover, they showed higher porosities, lower Gurley values than that of the polyolefin one. Cyclic voltammetry revealed that they were electrochemically stable in the voltage range of -0.5 to $4.5 \mathrm{~V}$ vs. $\mathrm{Li}^{0} / \mathrm{Li}^{+}$. They showed higher ionic conductivities than that of the polyolefin one in the temperature range of -10 to $60{ }^{\circ} \mathrm{C}$. Any internal short circuit was not observed for cells using them during charge-discharge tests. Cells using them showed better cycleabilities than that with the polyolefin one at -10 and $30^{\circ} \mathrm{C}$. Besides, they showed better rate capabilities than a cell with the polyolefin one.
\end{abstract}

Key Words : Nano-fiber, Nonwoven Separator, Lithium Ion Battery, Electrospinning

\section{1 緒 言}

近年，リチウムイオン電池（二次電池）は，携帯電話，ノ ートブック型パソコンなどの民生用小型機器の電源, 最近で は Ni-MH電池に代わる $\mathrm{HEV}$ ，電気自動車，電動工具，バッ クアップ電源など産業用機器関連への用途が急速に広がりつ つある，産業用機器の電源としての電池には，高容量化，高 出力などの電池特性はもちろん, 同時に高い安全性（熱安全 性, 高信頼性) が求められている.この電池のセパレータに は，通常ポリオレフィン系微孔膜が使用されている。リチウ ムイオン二次電池では, 充放電時にリチウムイオンがセパレ ータを介して移動するため, 電池性能（特性）は使用するセ パレータの厚さ, 空隙率, 透気度などの構造と密接に関連す る ${ }^{1)}$. ポリオレフィン系微孔膜は, 耐化学薬品性, 厚さ, 機 械的強度などリチウムイオン電池に適した特性を備えている ものの, 空隙率においては約 $40 \%$ と低い2), また，有機電解
液との親和性などの問題も有する ${ }^{3-5)}$.

一方，不織布を用いたセパレータはアルカリ系二次電池 （Ni-Cd，Ni-MH 電池）では幅広く用いられている. 不織布 のセパレータは，空隙率が微孔膜セパレータに比較して高く (50〜 90\%)，リチウムイオン電池の高出力化に有効である と考えられるものの, 一般的に基材が厚く, 空孔サイズが大 きいため, リチウムイオン電池に応用を考えた場合, 微短絡 の容易な発生, エネルギー密度の低下などの問題からリチウ ムイオン二次電池のセパレータとしてはあまり検討されてい ない. 不織布の孔径, 厚さ低減には, 使用する繊維の細繊維 化が重要な課題となる. しかし, 現状でのポリオレフィン系 繊維の最小繊維径は約 $1 \mu \mathrm{m} レ$ レ゙ルであり, 纎維径が微孔膜 の平均孔径より大きいため, 通常の不織布に用いられる一般 的な繊維原料, 製法により作製された不織布は, リチウムイ オン電池用セパレータへの応用は困難であった ${ }^{4,6,7)}$. 
前述のように，纎維径はリチウムイオン電池へ不織布からな るセパレータを応用させるために非常に重要であると考えら れる。最近では，エレクトロスピニング法によるナノサイズ の繊維径を有する不織布の研究，実用化の検討が盛んに，多 方面の用途で試みられている ${ }^{8)}$. 我々は，エレクトロスピニ ング法によって微孔膜セパレー夕に近似する厚さ，及び孔径 サイズを持つポリアクリロニトリル $(\mathrm{PAN})$ ナノ繊維不織 布セパレータを作製し, リチウムイオン二次電池のセパレー 夕としての評価を行った。ここでは，PANナノファイバー からなる不織布セパレー夕の作製方法，熱及び電気化学特性 に関する報告を行う。

\section{2 実 験}

重量平均分子量 50 万の PANを $N, N$ - ジメチルホルムアミ ド（DMF）（沸点： $153{ }^{\circ} \mathrm{C} ）$ に濃度 10.5 mass\%となるよう に溶解させ，紡糸原液（粘度：1200 $\mathrm{mPa} \cdot \mathrm{s}$ ）を用意した。

PANナノファイバーの紡糸に Fig. 1 に示すようなエレクト ロスピニング装置を用いた。装置は，紡糸用ポリマー溶液貯 蔵部，押し出し機，内径が $0.4 \mathrm{~mm}$ のステンレススチール製 針状紡糸ノズル，溶液に高電圧を印加するための高電圧電源, 纎維集積のための対向電極からなる．対向電極は，ガラスク ロスにポリテトラフルオロエチレン及び導電性粒子を含浸し, 焼成した捕集体を用いた。また，紡糸ノズルの先端と捕集体 の捕集表面との距離は $80 \mathrm{~mm}$ とした。

用意した PAN 紡系原液を，マイクロフィーダーを用いて 紡糸ノズルから紡糸原液を $1 \mathrm{~g} \mathrm{~h}^{-1}$ の量で吐出した。このと き, 高電圧電源で紡系原液に $14 \mathrm{kV}$ の電圧を印加して, 吐出 した紡糸原液に電界を作用させて䋊維化し，捕集体上に集積 させ平均繊維径 $380 \mathrm{~nm}$ の PANナノファイバー不織布を作製 した。このときの紡系時雲囲気は温度 $26{ }^{\circ} \mathrm{C}$ ，相対湿度 $23 \%$ に調整した。この後，作製したナノファイバー不織布をアル ミニウム製フレームに貼り付け，温度 $160^{\circ} \mathrm{C} に$ 設定したオー ブン中で 10 分間熱処理を行うことにより，静電紡系繊維中 に残留するDMF溶媒を除去した後，厚さ調整を行い，ナノ ファイバー不織布セパレータを作製した，次に，紡系時雲囲 気を温度 $26{ }^{\circ} \mathrm{C}$, 相対湿度 $13 \%$, 更に吐出条件を $0.65 \mathrm{~g} \mathrm{~h}^{-1}$ に 変更し，その後の熱処理，厚さ調整を $380 \mathrm{~nm}$ のものと同条 件で行い，平均繊維径が $250 \mathrm{~nm}$ のセパレータも作製した。 上記 2 種類の繊維径で 4 種類のPAN不織布セパレータを目 付と密度を調節し作製した。 Fig. 2 に平均繊維径 $380 \mathrm{~nm}$ の セパレータの電子顕微鏡写真（SEM）を示す.

SEM（Miniscope TM-1000, Mitsubishi, Japan）を用いて PANナノファイバー不織布の繊維径を測定した。透気度

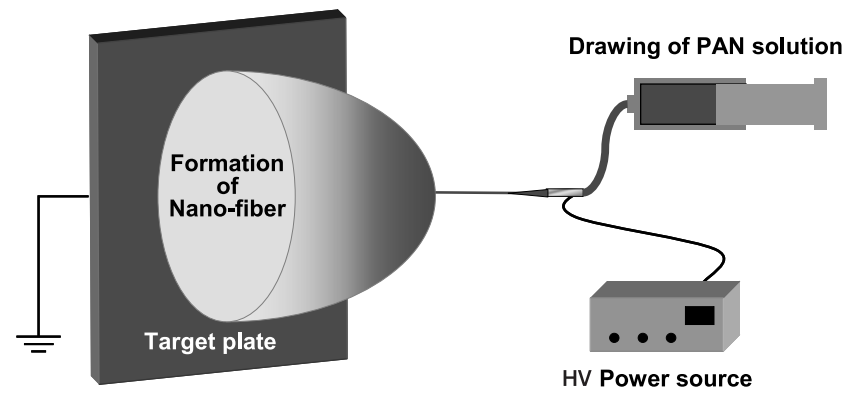

Fig. 1 Schematic depiction of equipment for electrospinning.
(Gurley)は, Gurley type Densometer（Yasuda Co., Japan) を用いて JIS P8177に基づいて測定を行った。

PANナノファイバー不織布の平均孔径はAutomated Perm Porometer（Porous Materials, Inc., USA）を用いて測 定を行った。バブルポイント法とは，膜を液体で満たした状 態で気体の透過挙動を測定し，膜にある最も大きな孔の大き さを評価する方法である。なお，孔径サイズは次式から求め られる。

$$
\mathrm{D}=4 \gamma \times \cos \theta / \mathrm{P}
$$

ここで D は孔径の直径（サイズ），Pはバブルポイントの 圧力, $\gamma$ は液体の表面張力, $\theta$ は液体 - 固体の接触角である.

セパレータの熱特性については，Thermo plus 8230 (Rigaku, Japan）を用いて Celgard ${ }^{\circledR} 2400$ （以下PP微孔膜） と PANナノファイバー不織布（以下 PAN不織布）の示差走 查熱量（DSC）により測定した。測定は，40-300 ${ }^{\circ} \mathrm{C} の$ 温度 範囲で $5{ }^{\circ} \mathrm{C} \mathrm{min}^{-1}$ の昇温速度にし，空気中で行った。

電解液との濡れ性は，動的接触角計（DAT1100, Fibro system ab, Sweden）を用いて時間経過に伴う接触角変化を 測定し評価した。

$120{ }^{\circ} \mathrm{C}$ で 8 時間真空乾燥した PAN不織布をセパレータとし, 正極に $\mathrm{LiCoO}_{2}$ 電極，負極にグラファイト電極を用いて作製 した 2032 型コインセルを用いて電気化学特性評価を行った。 正極は, $\mathrm{LiCoO}_{2}$ (Tanaka Chemical, Japan）とケッチンブ ラック及びポリフッ化ビニリデンを（90：5：5重量比） $N$ メチルピロリドンを用いて混合スラリーとし，アルミホイル に塗工した後 $140{ }^{\circ} \mathrm{C}$ で乾燥し正極シートを作製. 次に正極シ 一トを圧延した後，直径 $12 \mathrm{~mm}$ の円状に打ち抜いて使用し た．負極には，市販のグラファイト電極（Hohsen，Japan）

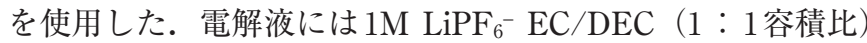
を用いた（Kishida Chemical, Japan）。
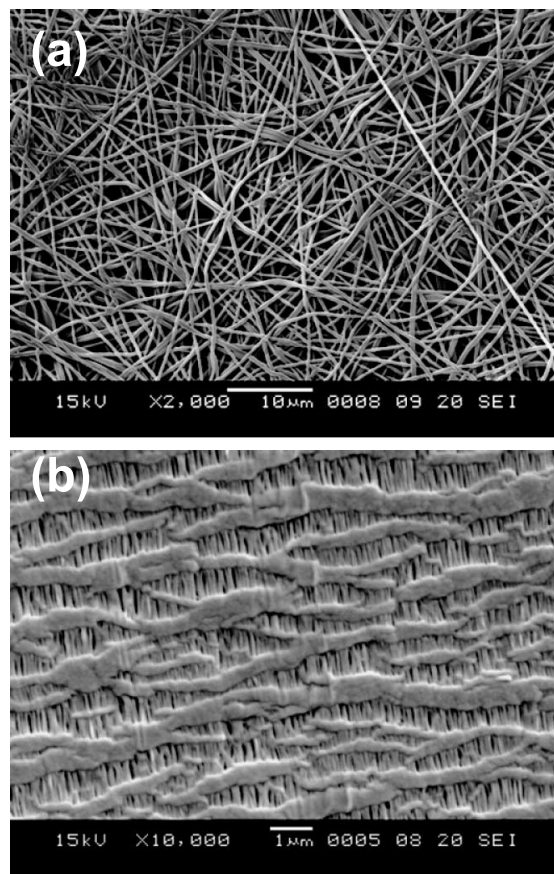

Fig. 2 SEM photographs of (a) PAN nano-fiber nonwoven and (b) the Celgard ${ }^{\circledR} 2400$. 


\section{3 結果と考察}

\section{1 PAN ナノファイバー不織布の物性評価}

エレクトロスピニング法よるPAN不織布の物性評価結果 と PP 微孔膜の物性值を Table 1 に示す。一般的に不織布セ パレータの厚みと孔径サイズは, 繊維原料の繊維径に依存す る．通常の不織布製セパレー夕は，繊維径 $1 \mu \mathrm{m}$ 以上の繊維 を用いているため，厚さが $80 \mu \mathrm{m}$ 以上でも平均孔径が $5 \mu \mathrm{m}$ 以上と大きい. そのため, 充放電時にリチウムデンドライト が成長し内部短絡が発生する恐れがあり，リチウムイオン二 次電池セパレータとしての使用は出来ない。一方, PAN不 織布は極細繊維径（250 nm と $380 \mathrm{~nm} ）$ からなるため，厚さ $25-35 \mu \mathrm{m}$, 平均孔径 $0.17-0.38 \mu \mathrm{m}$ で一般的なポリオレフ イン系微孔膜に近い值を有することが分かる。電池のサイク ル特性やレート特性は, セパレータの空隙率と Gurley 值に 依存する，空隙率は電解液の保持量に密接に関係し，高い空 隙率を有するセパレータは，より多くの電解液を保持するこ とが可能となり，より高いイオン伝導性 ${ }^{5)}$ とサイクル特性を 示すことが知られている. また, Gurley值は, セパレータ のイオン抵抗と密接に関連し, 低いGurley值は低いイオン 抵抗を意味する ${ }^{9)}$. 従って, PANナノファイバー不織布は, 従来のPP微孔膜比較して, 高い空隙率を有し, 非常に低い Gurley 值を有することより，良好な電池特性を示すことが 推測出来る。

Fig. 3 にPP微孔膜と PAN 不織布の示差走査熱量 (DSC) 法により測定した熱量変化を示す ${ }^{10)}$. $\mathrm{PP}$ 微孔膜より，163 ${ }^{\circ} \mathrm{C}$ でポリマー溶融による吸熱ピークが認められた。一方, $\mathrm{PAN}$ 不織布からは $250{ }^{\circ} \mathrm{C}$ まで熱量変化は観察出来ず， $253{ }^{\circ} \mathrm{C}$ と $284{ }^{\circ} \mathrm{C}$ で発熱ピークが観察された。いずれの発熱ピークも $\mathrm{PAN}$ の酸化反応のために現れたものと考えられる。以上の ことから PAN不織布はPP微孔膜より熱安定性が高いと考え られる。
セパレータの電解液への濡れ性は電池作製時の電解液注液 性や電池の充放電時における電極の体積膨張，収縮による電 解液の保持量に大きく影響するため, 濡れ性の良いセパレー 夕が求められている. Fig. 4 に時間経過における PP微孔膜 と電解液及びPAN不織布と電解液の接触角変化を示す. PP 微孔膜は $63^{\circ}$ の初期接触角を示し, 時間が経過しても接触角 の変化は見られなかった。一方 PAN不織布は, PP微孔膜よ り低い $48^{\circ}$ の初期接触角示し，時間の経過に伴って段々低く なり 0.3 秒後 $21^{\circ}$ の接触角を示した. 以上の結果より, PAN 不織布の濡れ性がPP微孔膜より高いことが分かる.

\subsection{PAN不織布の電気化学特性評価}

サイクリックボルタメトリー（CV）法を用いて PAN不織 布（PAN No.1）の電気化学的安定性評価を行った。 CV 測定 は，ワーキング電極に白金板，カウンター電極に金属リチウ ムを用いた 2032 型電池を用い, リチウム酸化還元電位に対

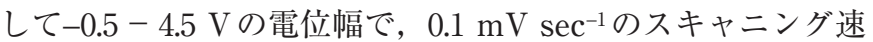
度で測定を行った. Fig. 5 に示すように，PAN分解由来の酸 化還元ピークは観測できず， $-0.5 \mathrm{~V}$ と $0.6 \mathrm{~V}$ 付近でリチウム の析出・溶解由来のピークが観測された。 以上の結果より, PAN不織布はリチウムイオン二次電池の作動電圧範囲で安 定であることが分かる.

Fig. 6 にPAN不織布の導電率測定結果を示す。導電率測定 は，金属リチウム電極の間にPAN不織布を挟んで作製した 電池を用い， $-10-60{ }^{\circ} \mathrm{C}$ の範囲で交流インピーダンス法によ り測定した。比較のため，PP微孔膜を用いて同様な試験を 行った。セパレータは正極と負極を分離する電池には必須不 可欠な部材であるが，セパレータの存在によりリチウムイオ ンの拡散が阻害され, 電池のバルク抵抗は 6 倍以上高くなる 1). 従って，電池の出力特性や寿命特性を向上するために, 導電率の高いセパレータが求められている. セパレータの導 電率測定結果より，PAN不織布は測定温度範囲内で，PP微

Table 1 Physical property of the polypropylene membrane and the PAN nonwovens.

\begin{tabular}{cccccc}
\hline Property & Celgard $^{\circledR} 2400$ & PAN No.1 & PAN No.2 & PAN No.3 & PAN No.4 \\
\hline Composition & PP & PAN & PAN & PAN & PAN \\
Thickness, $\mu \mathrm{m}$ & 25 & 33 & 35 & 25 & 30 \\
Pore size, $\mu \mathrm{m}$ & $<0.1$ & 0.28 & 0.38 & 0.18 & 0.17 \\
Porosity, $\%$ & 40 & 64 & 76 & 64 & 56 \\
Gurley, s $100 \mathrm{~cm}^{-3}$ & 730 & 380 & 380 & 250 & 11 \\
Fiber diameter, $\mathrm{nm}$ & - & & & & 250 \\
\hline
\end{tabular}

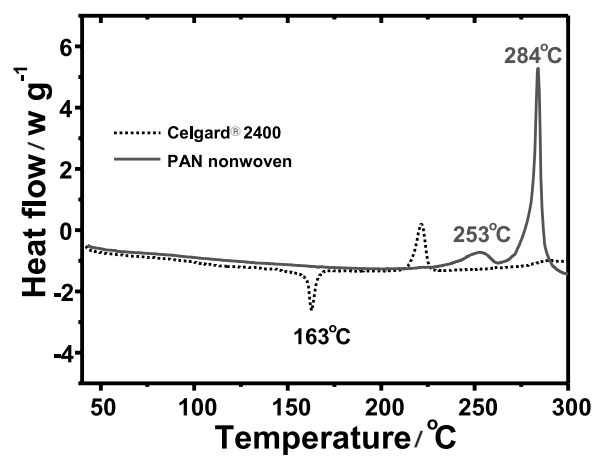

Fig. 3 Thermal properties of the polypropylene membrane and the PAN nonwoven.

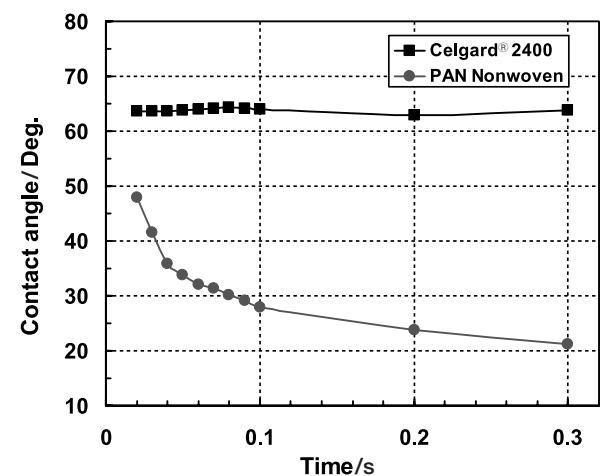

Fig. 4 Variations of contact angles between separators and electrolyte depending on the time. 


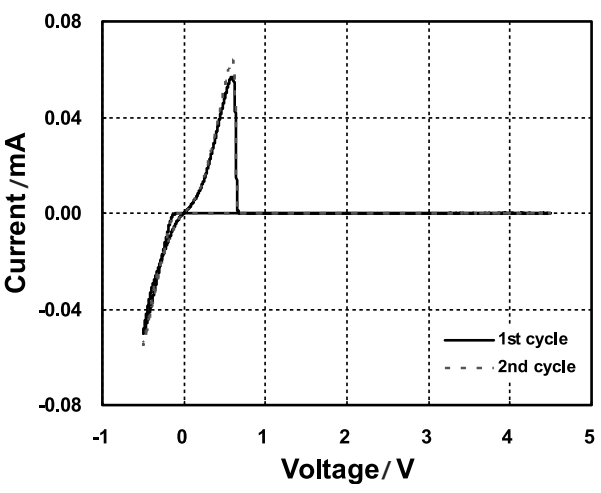

Fig. 5 Cyclic voltammogram of a cell with the PAN nonwoven in the voltage range of -0.5 to $4.5 \mathrm{~V}$ vs. $\mathrm{Li}^{0} / \mathrm{Li}^{+}$.

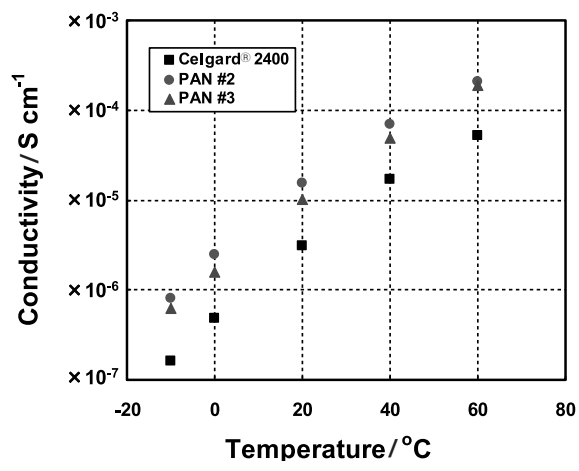

Fig. 6 Ionic conductivities of the Celgard ${ }^{\circledR} 2400$ and the PAN nonwovens.

孔膜より高い導電率を示すことが分かった。また，同じ PAN不織布でも空隙率が高くGurley值の低いPAN No.2の 方がNo.3より高い導電率を示したことからセパレータの導 電率は, その空隙率と透気度に密接に関連し, 空隙率と透気 度が高いほど導電率が高いと考えられる。

従来の不織布は, 緒言で述べたように平均孔径が大きく, 孔径分布も従来の微孔膜セパレータに比ベブロードな分布を 持つ.この性質から, 充放電時のリチウムデンドライト成長 により内部短絡が起こりやすい．以前我々が報告したように， 従来製法による不織布セパレー夕は，金属リチウム負極を用 いた電池は勿論，グラファイト負極を用いた電池においても， 充電時リチウムデンドライト成長による微小短絡が発生し, 安定的に充放電を行うことが出来なかった ${ }^{11)}$. Fig. 7 に $\mathrm{LiCoO}_{2}$ 正極，金属リチウム負極，PAN不織布（PAN No.1） を用いた電池で， $3-4.2 \mathrm{~V}$ 電圧範囲， $0.2 \mathrm{C}$ のレートで行っ た充放電試験結果を示す. Fig. 7-aに示すようにPAN不織布 は金属リチウム負極を用いた電池系でも微小短絡の発生がな く，安定的に充放電できることが分かった。更に，PAN不 織布を用いた電池は，ほぼ100\%の充放電効率を示し，20サ イクル後でも大きな容量低下もなく良好なサイクル特性を示 した（Fig. 7-b).このような PAN不織布を用いた電池の安 定な充放電特性は, PAN不織布がナノファイバーから形成 されているため, その孔径が小さく, 分布も狭いためたと考 えられる。

次に, グラファイト負極と $\mathrm{LiCoO}_{2}$ 正極で PP微孔膜及び PAN不織布を用いた電池のサイクル（寿命）特性評価を実
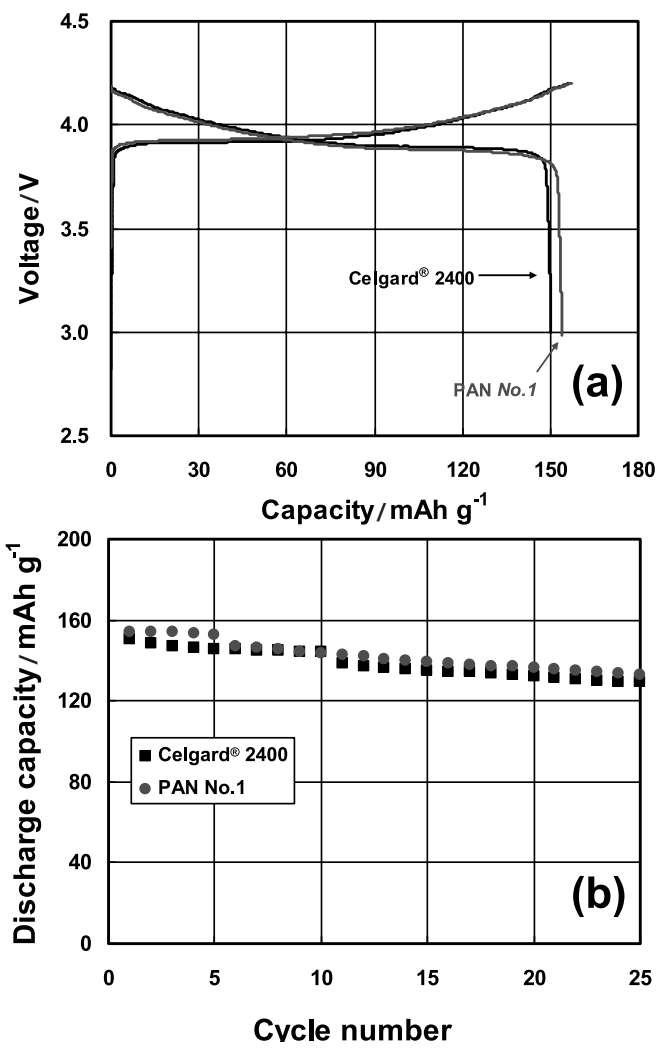

Fig. 7 (a) Initial charge-discharge curves and (b) cycle stabilities for cells, which consist of $\mathrm{LiCoO}_{2}$ cathode and $\mathrm{Li}$ metal anode, with the Celgard ${ }^{\circledR} 2400$ and the PAN nonwoven.

施した。初期サイクルでは， $0.2 \mathrm{C}$ のレートで $4.2 \mathrm{~V}$ まで定電 流充電を行った後，さらに定電圧で 5 時間充電を行った。 そ の後 $3 \mathrm{~V}$ まで $0.2 \mathrm{C}$ のレートで放電した. 2 サイクル目から は， $0.5 \mathrm{C}$ (定電流）のレートで充放電を繰り返した。得ら れた初期充放電曲線を Fig. 8-aに，サイクル特性を Fig. 8-b に示す. Fig. 8-a で確認出来るようにいずれの電池も初期开 イクルで安定な充放電曲線が得られ，ほぼ同一な放電容量を 示し，初期の充放電サイクルでは，電池性能の差は見られな かった. しかしFig. 8-bに示すように，充放電サイクルが進 むにつれて, 容量維持率が徐々に異なる挙動を示すことが分 かる.PAN不織布を用いた電池はいずれも250サイクル後に $76 \%$ 以上の容量維持率を示したが，PP微孔膜を用いた電池 は，68\%の容量維持率だった.PAN不織布を用いた電池が 良好な充放電サイクル特性を示した理由として, PP微孔膜 と比較し, PAN不織布が高い空隙率を有し, かつ良好な濡 れ特性を有することにより微孔膜より電解液保液特性が良い ものと考えられる.

Fig. 9 にPP微孔膜とPAN No.2を用いたグラファイト $\mathrm{LiCoO}_{2}$ 電池において, $-10{ }^{\circ} \mathrm{C}$ での低温充放電特性評価結果を 示す. 試験は, $30{ }^{\circ} \mathrm{C}$ で $0.2 \mathrm{C}$ のレートで 5 回充放電を繰り返 し，電池が異常なく作動することを確認した後に実施した. いずれの電池も雲囲気温度の低下により放電容量低下を示し たが，PAN不織布を用いた電池はPP微孔膜を用いた電池よ り放電容量低下も少なく, より安定なサイクル特性を示した。 80 サイクル経過後においてPAN No.2を用いた電池は正極活 物質の質量換算值で約 $96 \mathrm{mAh}^{-1}$ 容量を示すことに対し, 

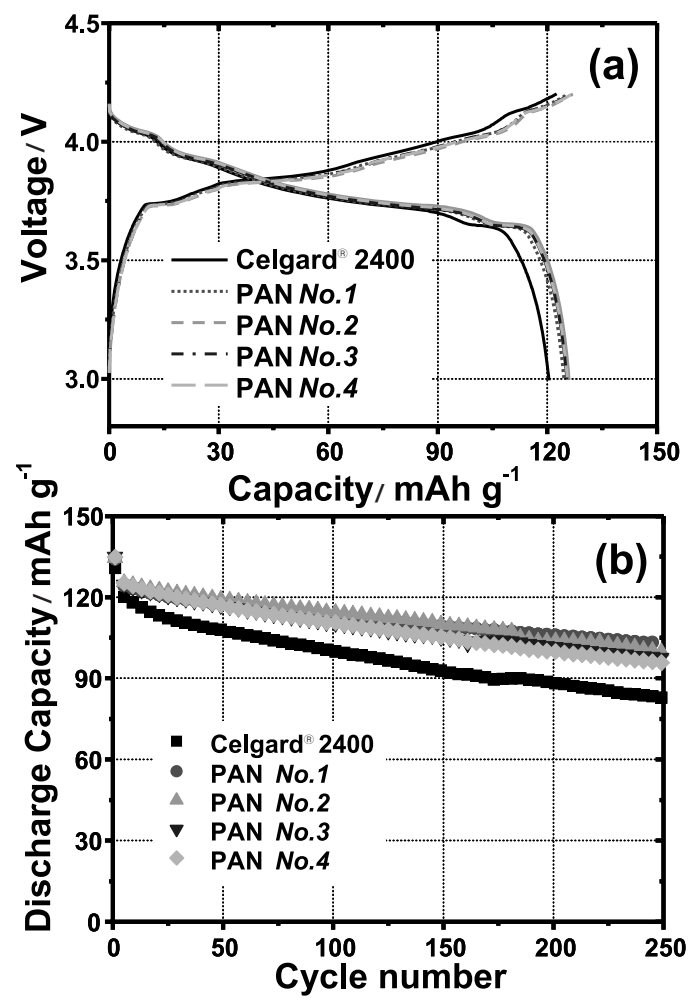

Fig. 8 (a) Initial charge-discharge curves and (b) cycle stabilities for cells, which consist of $\mathrm{LiCoO}_{2}$ cathode and graphite anode, with the Celgard ${ }^{\circledR} 2400$ and the PAN nonwovens.

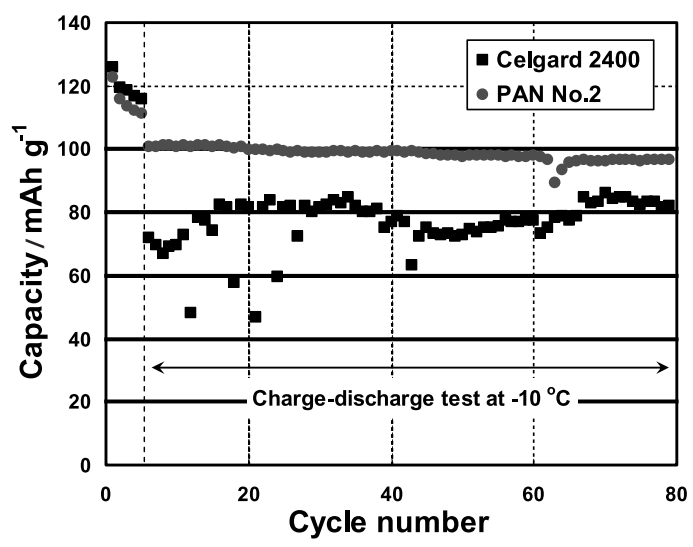

Fig. 9 Cycle stabilities of cells with the Celgard ${ }^{\circledR} 2400$ and the PAN nonwovens at $-10{ }^{\circ} \mathrm{C}$.

$\mathrm{PP}$ 微孔膜を用いた電池は約 $85 \mathrm{mAh} \mathrm{g}^{-1}$ のより低い放電容量 を示した。これらの結果より，PAN不織布を用いると，低 温においても PP微孔膜より高い電池特性が得られることが 分かる.

Fig. 10 にそれぞれのセパレータを用いたグラファイト $\mathrm{LiCoO}_{2}$ 電池のレート特性評価結果を示す。レート特性は, $0.2 \mathrm{C}$ のレートで充電した後， $0.2 ， 0.5 ， 1 ， 2 ， 4 ， 8 \mathrm{C}$ のレー トで放電し，それぞれのレートでの放電特性を評価した。 PP微孔膜を用いた電池は，1 Cのレートで初期容量の $90 \%$ を示したが，放電レートの増加につれて徐々に容量維持率が 低下し，4 Cでは初期容量の $42 \% ％ 8$ Cでは $7 \%$ しか得られ なかった（Fig. 10-a）。一方，PAN不織布を用いた電池は，

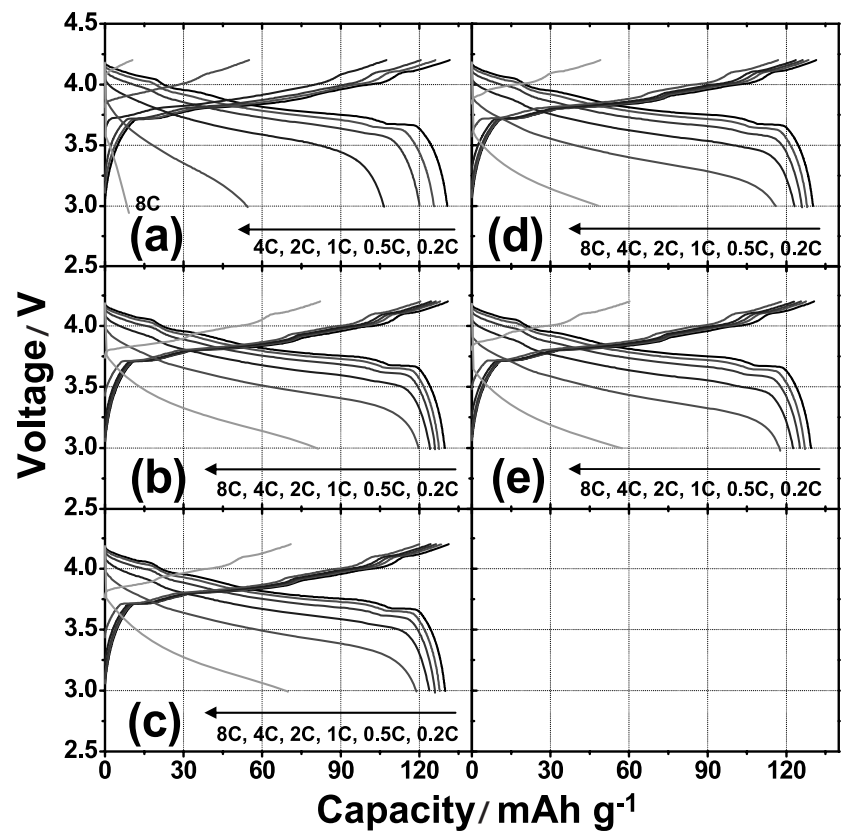

Fig. 10 Results of rate capability tests for cells with the separators; (a) Celgard ${ }^{\circledR}$ 2400, (b) PAN No.1, (c) PAN No.2, (d) PAN No.3 and (e) PAN No.4.

いずれも $8 \mathrm{C}$ で $37 \%$ 以上の容量維持率を示し, PP微孔膜を 用いた電池より優れたレート特性を示すことが分かった (Fig. 10-b-10-e). このような優れたレート特性は, PAN 不織布セパレータが高い空隙率と低いGurley值（透気度） を有するため, セパレータ内でのリチウムイオンの拡散抵抗 が低いことによるものと考えられる.

\section{4 結 論}

我々はエレクトロスピニング法によって微孔膜に近い厚み と孔径を有し，かつ高い空隙率を有するポリアクリロニトリ ル（PAN）のナノ繊維不織布を作製した. PANナノファイ バー不織布は金属リチウムの酸化還元電位に対して -0.5 から $4.5 \mathrm{~V}$ の範囲で安定であり, 金属リチウム負極を用いても安 定に充放出来ることが分かった. また， -10 から $60{ }^{\circ} \mathrm{C}$ の温度 範囲で従来微孔膜セパレータより高いイオン導電性を示し, 常温では勿論, 低温でも従来の PP微孔膜セパレータを用い た電池に比べ，良好な電池特性を示すことが分かった．更に， PANナノファイバー不織布が高い空隙率と高い透気度を有 するため，それを用いた電池が優れたレート特性を示すこと も分かった。

今回検討したエレクトロスピニング法でのナノファイバー 不織布は，空隙率を幅広く調節することも可能であり，この 適正化によりリチウムイオン電池のサイクル特性や充放電レ 一ト性能の向上に大きく寄与出来るものと考えている.

現在，エレクトロスピニング法によるポリアクリロニトリ ル (PAN) のナノ繊維不織布の製造については, 工業的に $1 \mathrm{~m}$ 幅での連続的な生産が可能になっているが, セパレー 夕への実用化に向けての課題は, 基布強度向上など機械的特 性の改良・改善は必須と考えられる.今後は, さらに機械的 強度の改善, 他ポリマーでのリチウムイオン電池特性への影 響検討などについて研究を進めていく. 


\section{文 献}

1) P. Azora and Z. Zhang, Chem. Rev., 104, 4419 (2004).

2) F. G. B. Ooms, E. M. Kelder, J. Schoonman, N. Gerrits, J. Smedinga, and G. Callis, J. Power Sources, 97-98, 598 (2001).

3) J. Saunier, F. Alloin, J. Y. Sanchez, and G. Caillon, J. Power Sources, 119-121, 451 (2003).

4) Y. M. Lee, J. W. Kim, N. S. Choi, J. A. Lee, W. H. Seol, and J. K. Park, J. Power Sources, 139, 235 (2005).

5) K. M. Abraham and M. Alamgir, J. Electrochem. Soc., 142, 683 (1995)

6) Y. M. Lee, N. S. Choi, J. A. Lee, K. Y. Cho, H. Y. Jung, J. W. Kim, and J. K. Park, J. Power Sources, 146, 431 (2005).
7) K. Gao, X. Hu, C. Dai, and T. Yi, Mat. Sci. Eng. B, 131, 100 (2006).

8) M. Kawabe, Seni gakkaishi, 64(2), 64 (2008).

9) D. Takemura, S. Aihara, K. Hamano, M. Kise, T. Nishimura, H. Urushibata, and H. Yoshiyasu, J. Power Sources, 146, 779 (2005).

10) T. H. Cho, T. Sakai, S. Tanase, K. Kimura, Y. Kondo, T. Tarao, and M. Tanaka, Electrochem. Solid-State Lett., 10(7), A159 (2007).

11) T. H. Cho, M. Tanaka, H. Onishi, Y. Kondo, T. Nakamura, H. Yamazaki, S. Tanase, and T. Sakai, J. Electrochem. Soc., 155, A699 (2008). 